\title{
A Fearsome Enemy (1); A history of sanitation in the British Army 1899-1914
}

\author{
Capt (Retd) SV Thompson \\ MA, FIBMS
}

15 Rearsby Road, Queniborough, Leicestershire, LE7 3DH

SUMMARY: The Boer War acted as a catalyst for military reform, including reform of the Army Medical Services (AMS). The subsequent medical debate was centred on the value of sanitation as a provision for war. This article $\frac{\overline{\bar{n}}}{\mathrm{n}}$ looks at the forces, political, military and economic, that propelled the provision of sanitation to a prominent position in the reforms of the army, and the effect this had on the status and role of the Royal Army Medical Corps (RAMC).

\section{Introduction}

The South African war began on the 11th October 1899 and gave the British, as Kipling said, 'no end of a lesson'. It proved at that time to be the longest and bloodiest war in British military history. Into this cauldron was placed a fledgling RAMC, barely a year old, and involved in a war where, once again, the British soldier suffered more from disease than from the enemy. Of 450,000 admissions to hospital only 27,000 were due to enemy action. Enteric fever and dysentery accounted for over 50 per cent of deaths from all causes. The war had a significant impact, not only of a political and military nature, but also in the sphere of military medicine. In the debate that followed the public clamour for change and reform, sanitation, not surprisingly, was pushed to the fore. Outrage gave way to anxiety when recruiting figures revealed further unpalatable truths; up to 70 per cent of working class recruits were unfit for military service. These figures generated a crisis in military circles concerning manpower levels as well as resulting in the Liberal welfare reforms in 1906. The war transcended the Nineteenth century into the Twentieth century and the subsequent political, military and medical reforms should be viewed as a conflict between old and traditional ideas and new and modern ideas. At a time when we are celebrating the centenary of the formation of the RAMC, this has a contemporary ring. It is therefore worth considering the forces that moulded the RAMC into the form that served the nation so well in two world wars.

\section{Reorganisation 1900-5}

The Army returned from the war to a new century, a new monarch, and a nation suffering a mood of pessimism; fearful of the future. British insularity was punctured by the war, partly by the failure to win a decisive victory but also by the rise of a powerful and aggressive Germany (2). The response was, what Searle describes as, 'a quest for national efficiency', in which experts had an important role (3). The development of a national movement to replace traditional methods with modern, efficient methods modelled on German practises occurred in all walks of life; in business, in industry, the state organisation and the military. The country divided into 'anti-efficient' and 'proefficient' groups. The Conservative government, faced with the irreconcilable task of economic retrenchment and a programme of radical reform, was not helped by an $\overrightarrow{0}$ opposition, tinged with pacifism, who did not have defence $\overrightarrow{\overrightarrow{.}}$ as a priority. The government's ambiguous attitude to the modern movement did not help their cause. Although they admired the German approach to efficiency, slavish 3 imitation was to be avoided, at all costs. Nevertheless they? had to make changes, any changes, to placate public $\vec{A}$ opinion. St. John Brodrick, as Secretary of State of War, had the unenviable task of reforming the Army. Although history has judged that Brodrick fudged the reforms, in reforming the RAMC he can claim a measure of success. $\mathrm{He}$ opened a door of opportunity which allowedenlightened officers to develop ideas that had profoufdid effects on the future status and role of the RAMC witlph the Army.

Brodrick's call for reform of the AMS promptedoa response from the British Medical Journal (BMJ) 'the ordye reform necessary is a change in attitude at the War Offece.

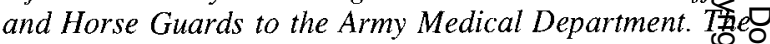
AMS, as mere appendages of the Army, could not instittmes the necessary changes to avert the medical disasters in South Africa'. This was typical of the pressure the $B M J_{0}^{\Perp}$ and the popular press put on Brodrick throughout $1900-1 \stackrel{\mathbb{Q}}{\complement}$ (4). The $B M J$ identified undermanning as a major problem $\overrightarrow{\vec{B}}$ in the AMS. Evidence to the Royal Commission into the 3 conduct of the war revealed that in a total of 8,500 medical personnel who served in the war only 23 per cent were RAMC. The $B M J$ called on Brodrick to come to terms with the medical profession, calculating that he had very few options given the political situation. There was no shortage of advice to Brodrick with the $B M J$ publishing a stream of correspondence and editorials to this end. The $B M J \mathbb{D}$ represented a powerful body of informed opinion, $;$ demonstrated by the decision of the British Medicalo Association to establish their own working party to investigate the reform of the AMS. It was an opinion? Brodrick could hardly ignore.

In September 1901 Brodrick succumbed to the pressures and established a committee of experts to examine and make recommendations on the future of the RAMC. With? remarkable alacrity the committee published its report in March 1902, with the recommendation that an Advisory Committee be established to monitor and advise the AMSO in the future. Of more immediate importance was the appointment of the DGAMS to the War Office Council and 
Army Board with the rank of Lt Gen a decision the $B M J$ greeted as befitting the dignity and responsibility of the office of the $D G$ '. From that point the DGAMS exerted an important influence on the Army at large in all that related to health. It was, however, the appointment of $\mathrm{Lt} \mathrm{Col} \mathrm{A}$ Keogh as chairman of the Advisory Committee that had the greatest effect on the future role of the RAMC. Keogh's first action was to successfully oppose the appointment of civilian sanitary specialists to the committee, thus paving the way for the appointment of Maj D Bruce and Maj WH Horrocks. The $B M J$ commenting on the reforms stated 'the time has gone when the Army could be regarded as a refuge for the professionally incompetent or as an easy career in which playing at soldiers was an agreeable occupation'. Brodrick's reforms improved pay and conditions of service, which had a beneficial effect on recruitment. More importantly they removed the shackles imposed by a Victorian Army, and what emerged was a confident and assertive RAMC which could tackle the most debated subject in the country; efficiency. The loss of military efficiency due to disease could only be solved by establishing rules of field sanitation. Brodrick's reforms laid a firm base on which a sanitary organisation could be built.

\section{The Nation Expects}

The medical debate began before the end of the war on a national scale. Public opinion in 1900 , according to the $B M J$, involved a considerable proportion of the adult population seized with the ambition of reforming the medical services of the Army'. Public opinion is notoriously capricious but the Boer War had touched most people. Nearly everyone had a relative, or knew of someone in the war, and the public knew of the problems. 'Enteric unless stated otherwise' was a rider added to the War Office casualty lists; a poignant reminder of the extent of the disaster. The press, as usual, led the way. 'It is outrageous that in the country's hour of need 20 per cent of its fighting men should be in bed with a preventable disease' claimed the Broad Arrow in September 1901. This was the general theme of the press, with the thrust of its reporting against incompetence, waste and inefficiency (5). The debate was concerned almost entirely with sanitary organisation and transcended traditional social views. The theme of the debate was captured, appropriately, by Lord Roberts who, when giving evidence to the Royal Commission, stated 'the RAMC suffered from want of a special sanitary officer. Sanitation forms a most important part of the medical provision for all campaigns'. Throughout 1900-1 the $B M J$ published many letters in support of the premise that it was far more efficient to keep a soldier in health than cure him of a preventable disease. Later St. John Brodrick admitted that sanitation was a neglected branch of the military economy (6). Prominent among those in the medical profession who set the postwar agenda was Sir Frederick Treves, the correspondent of the $B M J$ in South Africa. He witnessed the tragedy and was unequivocally in favour of preventive medicine.

There is little doubt that by 1902, the year of Brodrick's reforms, sanitation was established as the most important subject of military medicine. The contribution of the Journal of the RAMC should not be underestimated. In 1907 a certain Col Forman complained that the tone of the Journal was 'too ultra-scientific, too strictly professional and especially too prominently bacteriological'. Col Forman may have represented the old school but his criticism needs some comment. The Journal, from its inception in 1903, had a growing impact on the development of ideas. In 1904 it stated its role was to convert the RAMC to a scientific Corps by publishing work of a high scientific standard. Analysis of Forman's observations show that sanitary science and its related disciplines dominated the pages of the Journal up to 1914. Its first editorial in 1903 was concerned with 'the enteric problem', a review of its nature and aetiology. From 1904 it published numerous papers concerning various aspects of sanitation of an army in the field. The suspicion that there was an editorial bias is supported by the fact that the editors from 1903-14; Maj RH Firth as Professor of Hygiene 1903-6, Major D Bruce as specialist in tropical medicine and Maj WH Horrocks as specialist in sanitation, were prominent experts in their disciplines. In addition Bruce and Horrocks served on the Advisory Committee as sanitary specialists. It is a reasonable assumption that the Journal represented the views of the establishment. In reply to Col Forman the Journal reminded him of its role and pointed out the importance of sanitation, citing the work of Maj Bruce on determining the cause of Malta fever, adding that this discovery alone will 'blot out 70,000-80,000 days of illness amongst our troops'. This episode underlines the power of the press and professional journals to affect opinion, and has historic precedence in the case of William Russell who, throụgh the pages of The Times, had an important role in affecting the post-Crimea medical reforms.

The solution was not long coming. In $1903 \mathrm{Lt} \mathrm{Col} \mathrm{RH}$ Firth addressed an audience of naval and military hygienists and coined the phrase 'sanitary effort' which he defined as organised sanitation (7). The disaster in South Africa was not due to lack of sanitary science but lack of sanitary effort. Firth proposed the establishment of a 'bureau' in the office of the DGAMS, headed by a sanitary specialist whose authority would be devolved through local sanitary officers. These would organise squads of trained men to police (sic) sanitary discipline in the field. Recognising that sanitation needed to be carried out in peace to be effective in war Firth advocated the establishment of a school of hygiene. Sanitation, according to Firth, should be a provision of war as any other war materiel. Firth estimated that sanitary effort would reduce the cost in money and the loss in military efficiency by a third. Couched in terms that appealed to military efficiency, Firth's words must have been music to the ears of the military faced with the prospect of engaging a European enemy who used conscription as part of his 
military planning. Firth was not alone in arriving at this conclusion. On the 15th. November 1901, over a year before Firth, a Dr Leigh-Canney in an address at the Royal United Services Institute to a military audience, which included Firth, laid out his plans for the future of sanitation (8). It included much of what Firth was to state in 1903, albeit in an un-military way. More eccentric than expert Leigh-Canney carried out a one man crusade to bring the scale of the problem to public attention. He lobbied Members of Parliament and was not adverse to going to the top, even contacting Lord Roberts with his ideas. Leigh-Canney is recognised by some as being the first to bring the situation to the attention of the nation. It illustrated the depth of feeling of the general public as to the value of sanitation to the army. Firth's plans come to fruition when the school of hygiene was established in 1906 and by 1908 the first sanitary company had been established. These were Firth's sanitary police and during the Great War 270,000 men wore the yellow brassards of the 'sanitary police' (9).

\section{A Military Crisis}

Military anxiety had existed since the Crimea with the realisation that engaging in a wasteful war with no system of reserves was clear folly. Cardwell's reforms in the 1870's aimed to correct this and counter Prussian militarism; the Franco-Prussian War of 1870-1 had concentrated British military minds to the vast campaigns of their continental neighbours who used conscription as part of their military strategy (10). The defence of India, and countless frontier wars overstretched the army, leaving Cardwell's reforms in tatters. Although defence estimates in the 1890 s called for an army of 500,000 , to provide the force for South Africa the War Office stripped Britain's defences and denuded the Empire; 'we have got the whole of the Army out of the country and now the War office is face to face with how to make a new one' claimed ArnoldFoster in the Commons in 1900. By 1903 low recruitment, the poor state of the nation's health and lack of an organised reserve had created a crisis. The period was characterised by an unwillingness by the military to assimilate sanitation as part of military doctrine, which prompted The Hospital, in 1906, to remark 'combatant officers have grown up in an atmosphere in which all knowledge of physical science has been excluded'. It is suggested by some historians that the Army Medical Department, in the Nineteenth century, suffered from a Victorian prejudice against science in an army that valued the classical education of a public school, a prejudice it shared with the Royal Artillery and Royal Engineers (11). There is evidence that the 'old guard' of the Army distrusted sanitary reform, a fact recognised by Outlook in August 1901 when it stated 'neglect of sanitation is in the same callous spirit that in former generations throttled our soldiers with stocks and crossbelts'. The slow pace of sanitary reform prompted The Times, in 1905, to draw a comparison between the warlike and 'the merely military', implying that lack of sanitary reform was because the War
Office was not warlike enough. The press also found it illogical that sanitation formed no part of normal military training; 'we educate our soldiers to control their cartridges but allow them to squander food and water', claimed the Broad Arrow in September 1901. The British soldier may have been a social outcast but, in the words of Kipling, "was the saviour of his country when the guns begin to shoot'. There were demands to look after his 0 health and 'protect the defender of the Empire' became a 흐 rallying call for the imposition of sanitary provision (12). There was a rising tide of opinion in the country at large $\mathbb{\mathbb { D }}$ that saw the connection between the provision of sanitation and the conduct of war.

The reason the military distrusted sanitary reform probably lies in the Clauswitzian doctrine which the Victorian Army adhered to, in which the medical services consumed valuable transport and supplies without contributing anything to the destruction of the enemy. Lord Wolsely, the C-in-C, had written in 1886 'there is no time for sanitary work' (13). 'No time' was a continual criticism with regards to medical support in war throughout the Nineteenth century. Lord Kitchener had aptly put the military dilemma to the Royal Commission; 'it was pills or bullets' he said. In Clauswitzian doctrine pills would always be jettisoned in favour of bullets. In $1908 \mathrm{Lt} \mathrm{Gedi}$ Sir Alfred Keogh DGAMS entered the fray and accepted this tenet when he told the Royal Institute of Public Healt 'an army does not go to war for its health. The first rule a military medicine is that military considerations must take priority. No commander will welcome a sanitary office who delays his advance, the role of sanitation is to produce sufficient healthy soldiers, at a given time, for an offensive: Time is an important requirement of all milita operations' (14).

\section{Science and Technology}

Medical science eventually came to the rescue of the $\overrightarrow{\vec{O}}$ situation and answered all military objections. There was $\exists$ an intensification of scientific research which resulted in a large number of scientific discoveries and innovations? aimed solely at the sanitary needs of an army in war. The examples were numerous; rapid chlorination of large scale water supplies, Horrock's rapid test for detection of contaminated water, blood tests for early diagnosis of $\overrightarrow{\mathbb{D}}$ typhoid and Wright's development of typhoid vaccine, (first used in South Africa with mixed results but improved with increasing knowledge of the typhoid bacillus). It is 3 doubtful whether the adoption of the principle of sanitation would have been as successful without this progress in the field of technology and science. Sanitary science became a focus for further research. This period therefore, at least as far as this author is concerned, was the golden age of medical science in the RAMC.

\section{Acceptance}

It was announced in the Commons in November 1904 that the training of officers in basic hygiene had commenced at Sandhurst. In fact training became a heated 
subject. Lord Roberts, echoing Firth's views, said that training in peace was important for the wellbeing of the army in war. The establishment of the school of hygiene in 1906 was part of a training programme in the army at large and between 1904-8 a mass of training manuals for all branches of the Army were produced. We must remind ourselves that the RAMC was part of the regular Army and not, somehow, different. Sanitary provision was part of a jigsaw that constituted the army, and one of many changes occurring at the time. New weapon technology, new tactics, improved communication and improved administration were occurring at the same time. The RAMC also felt it was necessary to occasionally remind people that it was a regular army Corps. In 1904 Sir William Taylor, in an address to officer cadets, talked of 'duties and responsibilities other than medical'. Firth spoke the language of the military, and so did Lt Gen Keogh. In fact when Keogh stated 'time is a most important factor in all campaigns', and Roberts spoke about sanitation in the same manner, there was a feeling that they spoke each others lines. What really helped was the development of, as Searle puts it, 'a cult of experts'. As the art of war was surrendered to the science of war the language of the expert was of statistics, economy and efficiency. It was applied to every branch of the army, and was a doctrine into which the RAMC settled quite comfortably. Science and professionalism were necessary, according to the Journal in 1904, for the 'Corps to take its rightful place in the Army'.

Brodrick, realised the vital part commanders played in sanitary matters, and commented that unless the paramount importance of sanitation was accepted by army commanders the RAMC could never effectively supervise the health of the army (15). This message was reinforced by Lt Col EM Wilson in an address given in Aldershot in 1907. Wilson's experience in examining sickness returns enabled him to assess the personality of each unit commander. Good commanders (i.e. those showing leadership) had the lowest levels of sickness and crime. But when Lt Gen A Keogh announced on the 18th. November 1908 'there are indications that henceforth sanitation, as an important factor in the maintenance of the fighting strength of an army in the field, will receive definite recognition from military administrators and military commanders', it was probably because commanders were convinced that sanitation worked. Evidence that sanitation was a viable military option was available from April 1906 when Surg-Gen M Koike of the Japanese Army disclosed the full statistics of the RussoJapanese war of 1904-5 (16). To many the impossible had been achieved; the ratio of battle casualties to those caused by disease was reduced to $1: 1.15$. The discussion that followed centred around the validity and accuracy of these figures. A study of the war reveals that Japan, with a smaller army than Russia, regularly matched them in vast land battles which consumed armies of over 100,000. The Japanese were in little doubt that it was due to the sanitary provisions Firth and others had been advocating.

\section{Haldane's Reforms 1906-10}

Although Brodrick had an influence in redefining the role of the RAMC it was the efforts of others who brought it to fruition. Most prominent were Richard Haldane, the Secretary of State for War in 1906, Lord Roberts, the C-in$\mathrm{C}$ and hero of South Africa and Lt Gen Sir Alfred Keogh DGAMS 1904-10. Although the simultaneous emergence of these men was not planned, there is a suggestion of manipulation between Roberts and Keogh.

Haldane, who cherished the Chancellorship, arrived at the War Office as a member of a Liberal party bent on economy and pacificism. Considering the political situation what Haldane achieved was nothing short of miraculous. Within six months he announced his objectives of major military reorganisation and economic retrenchment (17). To Haldane economy and efficiency were not incompatible. By the middle of 1906 his Regular Army formation, the Expeditionary Force, was in development, and by 1907 the comprehensive Territorial and Reserve Forces Act was on the statute books. Haldane recast the army for one role only; war in Europe. Anything irrelevant to that objective was cast aside (18). The Expeditionary Force was to be mobilised and deployed to France in fifteen days; it was the Edwardian equivalent of today's 'rapid deployment force'. The formation of this force resulted in large reductions in men and money but, as Haldane told the Commons, it was value for money; everyo penny spent was on fighting efficiency. In an army entering a war outnumbered ten to one, there was no roomo for passengers, the medical services would be less of ad burden, more of an asset. When the Expeditionary Force went to France in 1914 it contained its full complement of sanitary police.

Lord Roberts rose to national prominence by his victory in South Africa. He was a reformer, believing that the Army reforms of 1859-99 did not go far enough; the diehards of the old Stuart army remained entrenched in the War office (19). Roberts advocated the formation of the General Staff as recommended in the Hartington report of 1888 , a recommendation successfully shelved by successive Governments until Haldane's reforms. From the outset Roberts had been converted to the value of sanitary provision to an army in the field. As a member of the National Service League, which advocated a large standing army, Roberts reserved his criticism for the failure of the RAMC to expand rapidly in the war, a criticism he shared with Keogh. Roberts believed that the medical strength of the army should be ten per cent of the force and not, as in South Africa, three to four per cent. He believed that sanitation was part of the government's responsibility for equipping the soldier mentally, physically and mechanically for the trauma of war.

It was, however, Lt Gen Sir Alfred Keogh who played the major role in the adoption of sanitary measures. Service in South Africa had raised two anxieties in Keogh; lack of sanitary provision and a lack of a trained medical reserve. Haldane's reforms gave Keogh the opportunity to 
address both of these anxieties. In response to the observation that it was difficult to train enlisted practitioners in sanitary science, Keogh set about establishing specialised sanitary companies in the RAMC Territorial Force. With very little to go on Keogh contacted medical officers of health to enlist their expertise and experience in forming these units. What emerged, in April 1908, was the first embryonic unit of a unique nature, whose sole object was the enforcement of sanitary discipline; the sanitary companies. All of these units were of Territorial Force origin and, according to the official history, were directly responsible for the low level of disease that the army experienced during the Great War.

Keogh could not have achieved this without having the confidence of Haldane and Roberts. Haldane described Keogh as 'a friend and one of the most efficient administrators in the War Office who has a passion for excellence in the medical organisation of the army' (20). Keogh's relationship with Roberts though is open to speculation. The evidence shows that they shared similar views on sanitation and manning. Keogh's skill as an administrator had come to the attention of Roberts at Springfontain where, as Commanding Officer of No. 3 General Hospital, he had supported Roberts' force during a severe typhoid outbreak (21). At the same time Keogh had gained national prominence when The Times had reported on his 'admirable qualities' in dealing with the outbreak. Keogh's meteoric rise from major in 1899 to Lt Gen by 1904 is characteristic of the reforming zeal of the period. The BMJ described his appointment to DGAMS as ' $a$ break with the past', and his promotion marked the death knell of promotion by seniority in the RAMC. Whether his promotion was a result of the influence, or direct intervention, by Roberts is open to speculation. However there is a precedence as Travers produces evidence showing that senior officers often fostered the careers of 'protégés' in the Edwardian army (22). Keogh's achievement cannot be underestimated. He had been influential in the imposition of sanitary provision since his appointment as chairman of the Advisory Committee in 1902. His defence of the appointment of military sanitary experts not only furthered the cause of sanitary provision but also must have gained the approval of Roberts. At a time when many felt that the health of the army was too important to be left to the military it was another victory for the reformers, notably Roberts. His achievement is best demonstrated by results; the Boer War was the last war in which the British soldier suffered more from disease than the enemy.

\section{Conclusion}

There is a temptation by historians to ask the question 'what if'. It is risky as it inevitably leads to further questions of 'what if' with no satisfactory conclusion. Nevertheless it is worth indulging in, risky or not, as it reveals the impact sanitary provision had on military thinking and on the conduct of war. What if there had been no sanitary provision in 1914? The question of military efficiency had dominated the debate on sanitary provision in the army and the cornerstone of military planning in the Great War was the 'decisive offensive'. If there had been the level of sickness in the Great War as experienced in South Africa would there have been enormous offensives such as the Somme? And to sustain the offensive for month after month? There are many factors that affect an army's ability to conduct a war. John Keegan makes a strong case that, throughout history, limitations have been placed on warmaking and its usage (23). Apart from legal and moral restrictions most have been beyond the power of men to command, including such factors as weather and terrain, which often inhibited or prohibited the operation of war. Keegan refers to other, so called 'contingent factors', such as provisioning, quartering and equipping. These limited the scope, intensity and duration of war in many periods of history. As technology and wealth increased so the ability to neutralise these inhibitors increased. By 1914, for example, food could be preserved indefinitely by canning. It is the opinion of the author that sanitary provision is a further contingent factor. By 1914 the scourge of disease had been lifted from armies; soldiering had become a healthy occupation, nurtured in an improved environment of public health at home and at the front line. A combination of improved public health, decline in infant mortality and the maintenance of the health of the army in the field combined to provide recruits in the millions and maintain manpower levels in battle. Sanitary provision removed a restriction on the intensity and duration of war, and allowed the High Command to indulge in the wasteful battles of the war. Sanitation was not responsible for the enormous battle casualties, it merely fitted into the military definition of a 'humanised battlefield' where fire power was measured in rifles and not in advanced weapor? technology available (24). According to Travers it was the failure to grasp the tactical and strategic significance of these new weapons that resulted in the horrendous battle casualties. This was only understood when the rising casualties eventually sapped morale.

A conclusion of this kind of course raises the question of the humanitarian aspect of medical provision; Russell in the Crimea used the words compassion and humane to describe the work of the AMD. In the period under discussion these words had been replaced by efficiency and waste. To conform to the needs of the military, humanitarianism seems to have been sidelined. Ideas at large in society such as the prevalence of social Darwinism seem to add weight to this view. Firth, for example, in 1907 wrote 'we all agree that, if we are to hold our own with foreign countries, we must have plenty of children to furnish workers and fighters'. He was writing about the falling birth rate and 'survival of the less able and a dearth of ability'. There was a widespread concern in Edwardian Britain that the falling birth rate threatened Britain's world position. By 1914 the population of America and Germany exceeded Britain's. In addition German military might was a direct threat to British security. A further point that enters the discussion is the concept of the Sanitary Companies as medical. Many of the officers were non-medical, and they did not deal with 
'patients', they dealt in numbers and statistics, and in the Great War many resorted to wearing military police brassards to enforce sanitary discipline; not exactly the mark of a humanitarian organisation. Additionally Beveridge's war diary creates the impression that these units were removed from the mainstream RAMC, in fact removed from the war (25). Beveridge's diary is remarkable for one fact, the almost total absence of reference to the apocalyptic battles raging around them. Beveridge's diary is a monotonous record of the fight against Russell's 'unseen enemy'.

The military advantages of sanitary provision were, and still are, important. The maintenance of health reduced the burden on an army, releasing vital transport for example. It also gave commanders medical intelligence as armies were now able to operate in unhealthy areas. The proliferation of biological weapons seems to confirm the position disease has in the conduct of war and the severe tax it places on an army's ability to operate effectively. Man made disease has added to the risk inherent in any campaign and reinforces the need to maintain vigilance. Today in a world of uncertainty, where our troops continue to have an operational role outside of the United Kingdom, it remains necessary to provide the kind of medical cover that was developed in 1903. At a time when the army is also used increasingly in a humanitarian role it provides the means to bring relief to ravaged areas of the world. The professionalism and scientific knowledge of the RAMC is needed as much today as it was in 1903 when the Journal first identified it as a necessary requirement. Sir William Taylor in 1904 had a vision that the 'RAMC would solve all the medical problems of the Empire'. The Empire may have gone but the role Taylor identified remains.

\section{REFERENCES}

1. LAMBERT AND BADSEY. The war correspondents. The Crimea War. (Stroud 1994). p 17. William Russell, on the 31st. March 1854, stated 'inaction brings listlessness and despondency, and in their train follows disease. What we have most to fear in an engagement is an enemy that musket or bayonet cannot meet or repel'. Russell was correspondent for The Times and his war time dispatches combined the bravery and steadfastness of the British soldier with his wretchedness. Russell's accounts of the war had a profound affect on middle class Victorian society. Russell was not alone in using 'enemy' to describe disease and the fear it produced. Letters from soldiers to home in the Nineteenth century expressed fear, helplessness and a stoical resignation. Ensign William Keep serving in the Walcheren campaign wrote 'we have a worse enemy in the disease which is thinning our ranks from which we have neither protection, nor relief'. Kipling in his poem 'Cholera Camp' captures the mood of the British soldier admirably, full of cynicism and black humour.

2. STEINER Z. Britain and the origins of the First World War. (London 1977) p 18-21; The Boer War as a catalyst.

3. SEARLE G. The quest for national efficiency. (Oxford). p 35-43.
4. Leigh-CANnEy. Memorabilia. (RAMC muniment collection) 1202. This is a unique collection of press and journal reports covering the period $1900-6$ and contains hundreds of reports from the United Kingdom and around the world. They all refer to the question of sanitation.

5. LEIGH-CANNEY. Memorabilia. (RAMC muniment collection) 1202.

6. Brodrick St. JoHn. Letter to The Times. (RAMC muniment collection) 1202.

7. FIRTH R. Address to military and naval hygienists, London 1903. (RAMC muniment collection) 1202.

8. EDITORIAL. Address by Leigh-Canney to Royal United Services Institute, 16th. November 1901.

9. MACPHERSON et al (Ed). Official history of the AMS 1914-18. Hygiene of war. Vol. 1. (HMSO 1923).

10. HAMER WS. The British Army, civilian and military relationship, 1885-1905. (Oxford 1970).

11. Simon and Bradley. The Victorian Public School. Studies in the development of an educational institution; a symposium: Ed. Simon and Bradley. (Dublin 1975). p129-46. Militarianism and the Victorian Public School.

12. LeIGH-CANNEY. Memorabilia (RAMC muniment collection) 1202.

13. WOLSELY Lord. Soldiers field pocket book 1886. p 110. (RAMC muniment collection) 965.

14. KEOGH A. The result of sanitation in efficiency of armies in peace and war. Lecture to the Royal Sanitary Institute, 18th. November 1908.

15. BRODRICK ST. JoHn. Letter to The Times 6th. January 1906. (RAMC muniment collection) 1202 .

16. KoIKE M. Address on the Japanese AMS achievements in the Russo-Japanese war 1904-5. Reproduced in the Journal of the RAMC April 1906. $\mathrm{p}$ 624-631.

17. HALDANE RB. Richard Burdon Haldane. An autobiography. (London 1929). p 168-210. The Liberal government and the army.

18. DUnLOP J. The development of the British Army 18991914. (London 1938). p 231-266.

19. HAMER WS. The British Army, civilian and military relationship, 1885-1905. (Oxford 1970).

20. HALDANE RB. Richard Burdon Haldane. An autobiography. (London 1929). p 168-210. The Liberal government and the army 1905-1910.

21. MAY R. The forgotten general. A short biography of Lt General Sir Alfred Keogh. (RAMC muniment collection). 1799.

22. TRAVERS T. The killing ground. The British Army, the Western front and the emergence of modern warfare, 1900-18. (London 1987).

23. KEEGAN J. A history of warfare. (Pimlico 1993). p 63.

24. Travers T. The killing ground. The British Army, the Western front and the emergence of modern warfare 1900-18. (London 1987). p 62-84. Morale, fire-power and technology.

25. BEVERIDGE WWO. War diary of ADMS (Hygiene). 1914-19. (RAMC muniment collection). 543. 